\title{
Integrating Cell Phones into a Chinese High School EFL Classroom: Students' Attitudes, Technological Readiness, and Perceived Learning
}

\author{
Feihong Wang \\ Xin Chen \\ Virginia Polytechnic Institute and State University \\ Weini Fang \\ Xiamen Songbai Secondary School
}

\begin{abstract}
Although explorations on cell phone-based learning (C-learning) in the field of teaching English as a foreign language (EFL) has been gaining increasing attention in the last 10 years, the explorations are constrained mainly to distance language teaching. Researchers have pointed out that mobile devices are most effective when combined with group activities, traditional educational activities, and other information and communication technologies (Librero, Ramos, Ranga, Trinona, \& Lambert, 2007; Stead, 2005). The purpose of this study was to investigate the integration of a C-learning activity into a traditional EFL classroom by looking at students'attitudes, technological readiness, perceived learning, and perceived appropriateness of the activity design. A total of 96 high school students from Xiamen, China participated in the study. Students'survey responses, reflection papers, and final projects were collected and analyzed. Findings of the study indicated that students enjoyed the activity. They found the activity interesting, inspiring, and effective for their English learning. Students had no technological anxieties related to the cell phone use. This study can contribute to the discussion on integrating cell phones for EFL teaching by providing a sample activity as well as students' possible perceptions and attitudes toward the activity.
\end{abstract}

Keywords: Cell phone-based learning, English as foreign language, Mixed methods

\section{Introduction}

Cell phone-based learning (C-learning), as an instructional approach, has been gaining increasing attention in the field of teaching English as a foreign language (EFL) in the last 10 years (e.g., Cavus \& Ibrahim, 2008, 2009; Librero et al., 2007; Saran, Seferoglu, \& Cagiltay, 2009; Thornton \& Houser, 2001). The review of literature, however, indicated that the exploration of C-learning in EFL teaching had been limited mainly to distance language teaching in which cell phones were used as mobile devices to receive or access instructional materials (Ally, 2009; Attewell, 2005; Cavus \& Ibrahim, 2008, 2009; Saran et al., 2009). As Roberson and Hagevik (2008) pointed out, the integration of cell phones into the curriculum could be as varied as the cell phones themselves. Mobile devices are most effective when combined with group activities, traditional educational activities, and other information and communica- 
tion technologies (Librero et al., 2007; Stead, 2005). For these reasons, this study explored the C-learning approach from a different angle: integrating cell phones into a traditional EFL classroom instead of distance education. The exploration and research in this project were formed by social constructivist principles in EFL teaching and learning. Design-based research was believed to be specifically appropriate for studies on technology - enhanced learning environment (Wang \& Hannafin, 2005). The study applied the design-based research approach to investigate related issues and problems in order to determine practical solutions in C-learning.

English language competency has become a crucial asset that makes career differences for Chinese people since the introduction of the liberal policy in the late 1970s (Gao, 2009; Griffith, 2008). Since then, a large portion of Chinese population has been eager to increase their English abilities. In addition, the use of cell phones among Chinese students is very extensive. For example, Chinese high school students have almost 100 percent cell phone ownership (Yi, 2010). On the contrary to the passion in English learning and the high percentage of cell phone ownership, the exploration on C-learning in EFL teaching is insufficient and hard to locate in China. The purpose of this study is to investigate the integration of cell phones into high school EFL classrooms in China by looking at students' attitudes, technological readiness, and perceived learning. The efforts of this study have been to explore: a) how cell phones can be integrated into traditional high school EFL classrooms, b) the Chinese students' attitudes and technological readiness for using cell phones for English learning projects, c) the Chinese students' perceived learning through the $\mathrm{C}$-learning project, and d) the appropriateness of the design of the C-learning project for high school EFL learning in China.

\section{Review of Literature}

\subsection{C-learning in EFL Teaching}

Using cell phones to facilitate EFL teaching is one of the earliest research trends in C-learning (McNicol, 2004). Being passionate about English learning, the attempts to apply C-learning to EFL teaching have been explored worldwide (Roberson \& Hagevik, 2008). Cavus and Ibrahim (2008, 2009) explored sending text messages to undergraduate students as a way to teach new technical words in Northern Cyprus. In Turkey, Saran et al. (2009) sent multimedia messages to students in order to improve students' pronunciation. Librero et al. (2007) explored the possibilities of using cell phones to offer formal and informal English education in Mongolia and the Philippines. Among Asian countries, Japan had been the pioneer in the Clearning research trend. Thornton and Houser (2001, 2005) provided learners with series of mini-lessons over cell phones. Taylor and Gitsaki (2003) used the browser function of cell phones to perform internet searches as an learning activity. Kiernan and Aizawa (2004) conducted a task-based English learning activity through cell phones.

Although the exploration of C-learning was not a new topic, the exploration of C-learning in EFL teaching had not exceeded its original format of distance language teaching. As early as 1988, Twarog and Pereszlenyi-Printer (1988) used telephones to provide distant language learners with feedback and assistance. Today, cell phones are still used mainly for receiving or accessing instructional content anywhere and anytime (Ally, 2009; Attewell, 2005; Cavus \& Ibrahim, 2008, 2009; Saran et al., 2009). Consequently, the C-learning investigations have centered two cell phone functions, text messaging, and Web access. In addition, because the focus of C-learning has been put on using cell phones for distance education purposes, the exploration of integrating cell 
phones into traditional EFL classrooms has not been gaining enough attention.

In the last 10 years, cell phones have evolved from simple vocal communication gadgets to palm-sized, high-tech packages that can serve as mini-computers, telephones, and cameras to transfer text, pictorial, video, and audio files (Prensky, 2005; Wang \& Higgins, 2006). As Roberson and Hagevik (2008) pointed out, "the different ways for integrating cell phones into the curriculum can be as varied as the phones themselves" (p.3). Cell phone functions, such as a dictionary, a camera, games, and a calculator can all be used for educational purposes (Cui \& Wang, 2008; Lucking, Christmann, \& Wighting, 2010). In other words, C-learning can definitely go beyond the distance learning approach. Researchers have pointed out that mobile devices are most effective when combined with group and traditional educational activities (Librero et al., 2007; Stead, 2005). In this study, group setting and the integration of the traditional classroom-based instructional approach were important features. Cell phones were used as convenient digital gadgets instead of instruction receivers to contribute to high school EFL teaching in China.

\subsection{C-learning in EFL Teaching in China}

China is the world's largest wireless market (Leske, 2008). In 2009, China sold 35.65 million cell phones (Wang, 2009). The cell phone ownership among Chinese students is very high with almost 100 percent cell phone ownership among high school students (Yi, 2010). The conceptual discussions on C-learning in EFL teaching are extensive in China. Some English learning Web sites also send mini-English lessons to their members through cell phones. Despite the heated discussion and commercial promotion of using cell phones for distance English learning, the empirical exploration on C-learning in formal English education settings was hard to locate and few have had paid at- tention to the activity design. Researchers suggested that the success of C-learning depended on an appropriate activity design to persuade students to use cell phones for educational purposes (Librero et al., 2007; Prensky, 2005; Pursell, 2009). Therefore, a C-learning activity was carefully designed for this study.

\section{Method}

\subsection{Activity Design and Procedure}

Wang (2010) suggested a combined taskbased learning approach for integrating cell phones into traditional EFL teaching. The combined task-based learning approach uses Willis' (1996) task-based learning as the design framework, specifies the task to be authentic, and requires the task to be conducted in a collaborative learning setting. Willis' task-based learning includes three components: task, planning, and report (Willis, 1996). In the task phase, students complete the task without the direct involvement of the instructor. In the planning phase, students prepare the report about their results and their discoveries. At last, in the report phase, students report to the entire class or exchange their reports with other students to compare the results. Wang (2010) also suggests the concept of technology transparency for Clearning, which emphasizes the natural integration of cell phones into learning activities. In other words, the use of cell phones to complete a specific learning task should be convenient. Putting together, according to Wang (2010), the design of a C-learning activity for EFL teaching includes four principles: 1) each activity includes three components: task, planning, and report; 2) the activity is authentic; 3) the activity should be conducted collaboratively; and 4) the integration of cell phones should be natural.

Following the design principles suggested by Wang (2010), in this study, students were put into small groups consisted of three or four students to work on an authentic learning task: 
presenting English street logos and signs in Xiamen, China by using Microsoft Office PowerPoint. Students were required to locate and take pictures of English street logos and signs by using the embedded camera in their cell phones after school. After taking the pictures, members of a group gathered to pool their pictures together to develop a PowerPoint presentation. In order to provide students with more control of the task and encourage creativity, each group was allowed to choose their own topic, angle, and approach to complete the task. After the completion of the project, each group shared their presentations with the rest of the class in the form of peer teaching. The entire activity took four weeks to complete. The data collection happened shortly after the completion of the learning activity.

\subsection{Study Design}

This study took the design-based research approach to investigate issues and problems related to the C-learning project. In designbased research, researchers and the instructor collaboratively managed the research process. Through this approach, the instructor and the researcher designed and implemented the intervention systematically, as well as refined and improved the initial design through the activity (Wang \& Hannafin, 2005).This study applied mixed-methods data collection and analysis approach. Mixed methods, as defined by Creswell, Clark, Gutmann, and Hanson (2003) are:

the collection or analysis of both quantitative and qualitative data in a single study in which the data are collected concurrently or sequentially, are given priority, and involve the integration of the data at one or more stages in the process of research. (p.212)

The reason of collecting both quantitative and qualitative data was to have a comprehensive view of the research questions and find- ings by bringing together the strengths of both research methods (Creswell, 2005). This study collected a vast amount of data including students' survey responses, students' reflections papers, and their final projects. The qualitative and quantitative data were collected concurrently with the same priority. The integration of the data happened at both the data collection and analysis stages.

\subsection{Participants}

A total of 96 second-year high school students from Xiamen Songbai Secondary School participated in the learning activity. They took part in the group activity such as taking pictures and the presentation development. Participants' ages ranged from 16- to 19-years-old. Among them, 91 students completed the survey, which yielded a final sample of 74 students who had usable responses. A total of 93 students completed the reflection paper.

In terms of the participants' technology background, all the participants knew how to create a PowerPoint slide show. The participants, in general, presented two to six times in the class every semester. In addition, the participants used cell phones to make phone calls, take photos, and text each other during their daily life. Some participants even used cell phones for web surfing and game play.

\subsection{Instruments}

The researchers designed and developed two instruments for data collection: a survey questionnaire and a guided reflection paper. The questionnaire was used to evaluate the appropriateness of the C-learning approach for EFL teaching in China. The survey questions were divided into five parts. Part I included six, 4-point Likert-scales to measure participants' technological readiness for C-learning activities. Scales ranged from " $1=\mathrm{I}$ don't know what this means, $2=\mathrm{I}$ don't know how to do this, $3=$ 
I can do this, $4=$ I can do this well" in response to different cell phone functions. Part II and Part III collected students' attitudes towards using cell phones to complete the learning task as well as their perceived learning. They consisted of 13, 5-point Likert-scales ranged from " 1 = Strongly disagree, 2 = Disagree, 3 = Can't tell, 4 = Agree, 5 = Strongly agree." Part IV comprised two open-ended questions asking about three things participants liked or disliked the most in the learning activity. Part V dealt with participants' demographic and other relevant information.

A reflection paper was used to collect participants' thoughts and reflections of the learning activity. Because the instructor was concerned that students might have problems organizing their thoughts for the reflection paper, she suggested the inclusion of leading questions. Based on discussions with the instructor, eight leading questions were incorporated, including questions about the overall perception toward the activity design, perceived effectiveness of the activity for English learning, problems and issues of the activity, and suggestions for improving the activity. The inclusion of the leading questions made the reflection paper similar to a survey with open-ended questions.

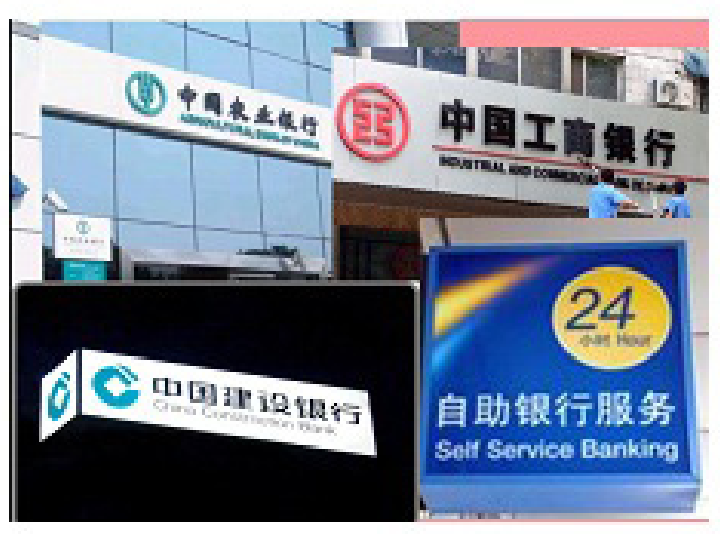

Bank Related

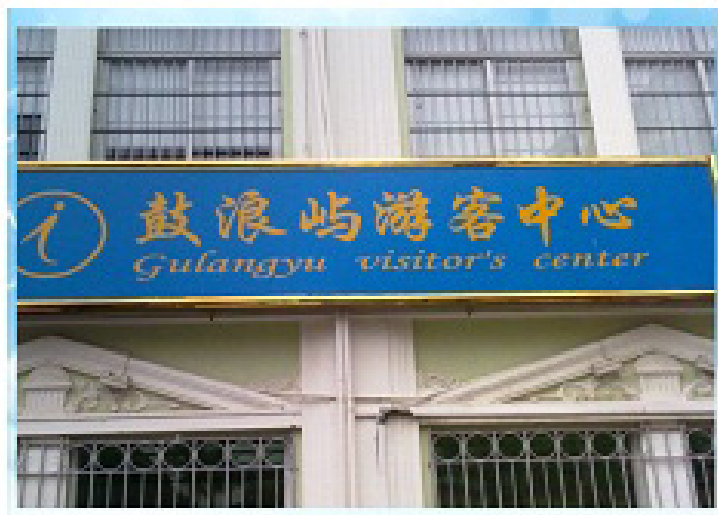

Visitors' Center

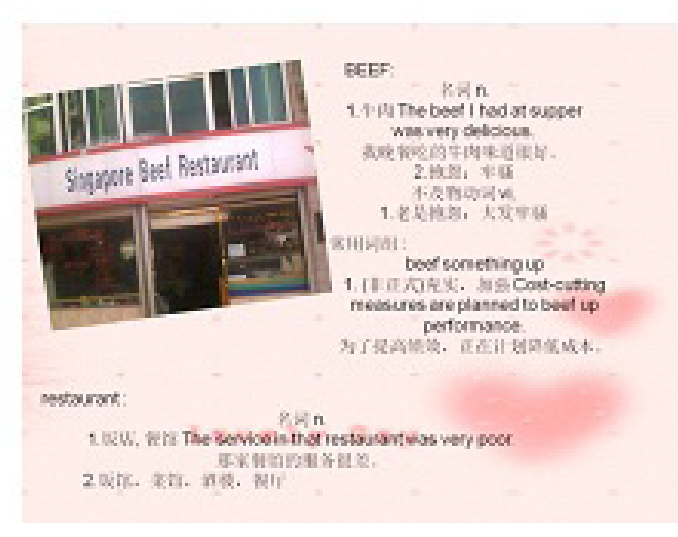

Beef Restaurant

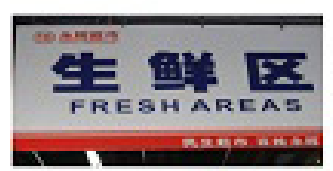

Economically underdeveloped areas

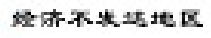

You can buy fresh fruit and vegetables in the market.

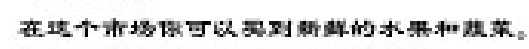

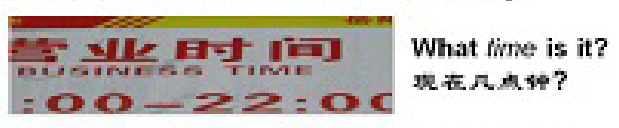

The company has done business with many countries.

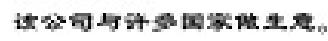

Supermarket Signs

Figure 1: Screen shots of students' PowerPoint slides. 


\section{Results and Discussion}

Students were grouped into 22 teams with each group having 3 to 4 members. At the end of the activity, each group designed, developed, and shared a PowerPoint presentation with the rest of the class. Students took approximately 697 photos of street logos and signs with some repeating images and themes. Students demonstrated their creativity through various ways of organizing the images for their presentations. Figure 1 shows the screen shots of some of the PowerPoint slide pages. Some groups tried to organize images according to themes such as English words used in banks or supermarkets, whereas some groups extended English words with sample sentences. Some groups used the entire slide page to show a single image that they thought was particularly interesting, whereas some groups used PowerPoint's animation function to present a group of images one slide page.

\subsection{Technological Readiness for C-learning}

Based on the quantitative data, students had sufficient cell phone skills for the C-learning activity. As shown in Table 1, responses to all of the questions about technological readiness had mean scores around 3.5 or 3.7. Therefore, generally speaking, students were able to use a variety of cell phone functions for the $\mathrm{C}$ learning activity such as taking pictures, deleting and editing pictures, and exporting pictures from cell phones to computers.

Table 1. Students' Technological Readiness for C-learning

\begin{tabular}{|c|c|c|c|c|c|}
\hline Questions & $\mathrm{N}$ & Minimum & Maximum & Mean & Std. Deviation \\
\hline $\begin{array}{l}\text { Q1. Operate various functions of my cell } \\
\text { phone (e.g. SMS, camera, playing music). }\end{array}$ & 73 & 3 & 5 & 3.71 & .485 \\
\hline $\begin{array}{l}\text { Q2. Take pictures by using the embedded } \\
\text { camera of my cell phone. }\end{array}$ & 74 & 3 & 5 & 3.73 & .477 \\
\hline $\begin{array}{l}\text { Q3. Export pictures from my cell phone to } \\
\text { a computer. }\end{array}$ & 74 & 2 & 5 & 3.73 & .531 \\
\hline Q4. Delete pictures in my cell phone. & 74 & 1 & 5 & 3.73 & .746 \\
\hline $\begin{array}{l}\text { Q5. Find and share pictures in my cell } \\
\text { phone with others. }\end{array}$ & 72 & 2 & 5 & 3.58 & .550 \\
\hline $\begin{array}{l}\text { Q6. Edit and organize the pictures to de- } \\
\text { velop a PowerPoint report. }\end{array}$ & 74 & 2 & 5 & 3.36 & .674 \\
\hline Valid N (listwise) & 71 & & & & \\
\hline
\end{tabular}

Although students were skillful with cell phone usage, several disadvantages of cell phones were exposed from the qualitative data. Some students claimed that their cell phones' screen sizes were too small to check the quality of the images immediately. Some students blamed the low resolution of their cell phones' embedded camera for deterring them from getting clear pictures sometimes. In addition, a couple of students mentioned that they did not have advanced cell phones with an embedded camera. One student indicated that he actually 
did not have a personal cell phone. This result indicated that although students might have sufficient technological skills for conducting a C-learning activity, the limitations of a cell phone's function might affect the successfulness of the activity. Other than making sure that students' cell phones have the function that is required for a learning task, instructors should also pay close attention to the performance of that function. For example, for a C-learning activity that is similar to this study, instructors should check the performance of the cell phone's embedded camera such as resolution.

Table 2. Students' Attitudes toward Cell Phone Usage

\begin{tabular}{|c|c|c|c|c|c|}
\hline Questiions & $\mathrm{N}$ & $\begin{array}{l}\text { Mini- } \\
\text { mum }\end{array}$ & $\begin{array}{l}\text { Maxi- } \\
\text { mum }\end{array}$ & Mean & $\begin{array}{l}\text { Std. } \\
\text { Deviation }\end{array}$ \\
\hline $\begin{array}{l}\text { Q7. I like bringing my cell phone along with me } \\
\text { on a daily basis. }\end{array}$ & 74 & 1 & 5 & 3.49 & .895 \\
\hline Q8. The camera in my cell phone is fun to use. & 74 & 1 & 5 & 3.57 & 1.048 \\
\hline Q9. I use the camera in my cell phone frequently. & 74 & 1 & 5 & 3.82 & 1.025 \\
\hline $\begin{array}{l}\text { Q10. It is convenient to use the camera in my cell } \\
\text { phone to complete this learning project. }\end{array}$ & 74 & 2 & 5 & 4.12 & .776 \\
\hline $\begin{array}{l}\text { Q11. I believe cell phones can be great learning } \\
\text { tools in the future. }\end{array}$ & 74 & 3 & 5 & 4.26 & .684 \\
\hline $\begin{array}{l}\text { Q12. I believe cell phones can facilitate English } \\
\text { learning. }\end{array}$ & 74 & 1 & 5 & 4.09 & .797 \\
\hline $\begin{array}{l}\text { Q13. It is fun to use cell phones to complete Eng- } \\
\text { lish learning projects. }\end{array}$ & 74 & 0 & 5 & 4.01 & .944 \\
\hline $\begin{array}{l}\text { Q14. I felt comfortable interacting with other } \\
\text { students to complete the learning project. }\end{array}$ & 74 & 2 & 5 & 4.22 & .745 \\
\hline Q15. This project was implemented very smoothly. & 73 & 2 & 5 & 4.03 & .745 \\
\hline $\begin{array}{l}\text { Q16. This project has been a positive learning } \\
\text { experience for me. }\end{array}$ & 74 & 1 & 5 & 4.38 & .716 \\
\hline $\begin{array}{l}\text { Q17. Using cell phones for learning purposes } \\
\text { confuses me more than it helps me. }\end{array}$ & 74 & 1 & 5 & 2.34 & 1.114 \\
\hline $\begin{array}{l}\text { Q18. Lectures are better than group activities for } \\
\text { me to learn new English words. }\end{array}$ & 73 & 1 & 5 & 3.40 & .968 \\
\hline $\begin{array}{l}\text { Q19. The project helps me to learn English vo- } \\
\text { cabulary in its real life situations. }\end{array}$ & 74 & 1 & 5 & 4.07 & .926 \\
\hline Valid N (listwise) & 73 & & & & \\
\hline
\end{tabular}

Volume 4, No. 1, October, 2011 


\subsection{Attitudes toward the C-learning Activity}

There were 13 survey questions investigating students' attitudes towards using cell phones as tools to complete the language learning activity. As shown in Table 2, questions No. 7, 8, and 9 were about students' attitudes towards cell phone use in general. Their mean scores were $3.49,3.57$ and 3.82. In other words, on average, students agreed that they liked using cell phones. Questions No. 10 to 19 explored students' attitudes towards using cell phones for this specific C-learning activity. Except for question No. 18, the mean scores were above 4.0. That is to say, students are positive about using cell phones to completing the learning activity.

As shown in Table 3, this study also found that there were significant correlations among students' expected project grades, their preferences of bringing cell phones on a daily basis, and the feeling of fun of using cell phones to complete English learning projects. In other words, the more fun students found in using cell phones either for daily use or for learning, the higher grades they expected for this learning activity.

Table 3. Attitudes and Expected Project Grades

\begin{tabular}{|c|c|c|c|c|c|c|c|c|}
\hline & & Q7 & Q8 & Q9 & Q10 & Q11 & Q12 & Q13 \\
\hline \multirow[t]{3}{*}{ ExpGproject } & $\begin{array}{l}\text { Pearson Correla- } \\
\text { tion }\end{array}$ & $.252^{*}$ & $.401^{* *}$ & .213 & .088 & .069 & .125 & $.369^{* *}$ \\
\hline & Sig. (2-tailed) & .032 & .000 & .070 & .459 & .560 & .292 & .001 \\
\hline & $\mathrm{N}$ & 73 & 73 & 73 & 73 & 73 & 73 & 73 \\
\hline
\end{tabular}

According to the qualitative data, students believed that using cell phones helped them understand more in completing the learning task. They also believed that the application of cell phones into learning English improved their English education in many ways. Some participants took C-learning as a new method to learn English. For example, one participant mentioned, "The camera function of cell phones enables a new way to learn English, because it can record everything that is worthy to be memorized anywhere, anytime" (Participant. 37).

In summary, these results indicated that students were both positive about using cell phones for learning purposes and this C-learning activity. The more the students enjoyed using the cell phone, the more the students liked the C-learning approach. This finding is also consistent with researchers' belief that today's students are "digital natives" (Prensky, 2001) who grow up with interactive digital tools (Oblinger, 2003). Matching the learning styles, habits, and interests of the students with appropriate instructional strategies is very important to produce effective learning outcomes (Prensky, 2001).

\subsection{Perceived Learning}

Responses of the six close-ended survey questions exploring students' perceived learning indicated that students felt that they learned a lot in this C-learning activity (see Table 4). All questions had mean scores roughly around 4. Students believed that their memorization and understanding of new words were enhanced by participating in this learning activity. 
Table 4. Students' Perceived Learning from the C-learning Project

\begin{tabular}{|c|c|c|c|c|c|}
\hline Questions & $\mathrm{N}$ & $\begin{array}{l}\text { Mini- } \\
\text { mum }\end{array}$ & $\begin{array}{l}\text { Maxi- } \\
\text { mum }\end{array}$ & Mean & $\begin{array}{r}\text { Std. } \\
\text { Deviation }\end{array}$ \\
\hline $\begin{array}{l}\text { Q20. The project is helpful to my learning of new } \\
\text { English words. }\end{array}$ & 74 & 1 & 5 & 4.03 & .740 \\
\hline Q21. I learned a lot through this project. & 74 & 1 & 5 & 3.97 & .721 \\
\hline $\begin{array}{l}\text { Q22. I can memorize and understand English } \\
\text { vocabulary better through these types of learning } \\
\text { activities. }\end{array}$ & 73 & 1 & 5 & 3.95 & .832 \\
\hline $\begin{array}{l}\text { Q23. I enjoyed sharing with and learning from } \\
\text { my group peers when working on the project. }\end{array}$ & 74 & 1 & 5 & 4.20 & .776 \\
\hline $\begin{array}{l}\text { Q24. My understanding of new English words } \\
\text { was enhanced by learning from other groups' } \\
\text { reports. }\end{array}$ & 73 & 1 & 5 & 4.00 & .833 \\
\hline $\begin{array}{l}\text { Q25. I want to have more similar learning proj- } \\
\text { ects in the future. }\end{array}$ & 74 & 1 & 5 & 4.08 & .976 \\
\hline Valid N (listwise) & 72 & & & & \\
\hline
\end{tabular}

The qualitative responses from the students also support the survey findings. All students believed that the learning activity was appropriate and meaningful because they "like taking pictures" (Participant 88), and they found "English is not merely in books" (Participant 27), "English is everywhere" (Participant 41). By seeing how English was applied in daily life, students were keenly aware of the importance of learning the language. Some students pointed out that "the confidence of learning English was enhanced because English was all around us and was not as hard as what I thought before" (Participant 38). They also found this learning activity "inspired them to find other effective ways to learn English" (Participant 37).

All but one student believed that this Clearning activity benefited their English learning because "this activity helped them learn new English words in a relaxed environment" (Participant 85), and "connected the knowledge with daily life" (Participants 28, 38, 40, $41,42)$, so that "they could better understand and memorize those English words" (Partici- pants $38,85,86)$. Only the students who did not think the activity was beneficial to English learning took the activity as merely a short period of entertainment.

Most students also held that in addition to improving their memorization and understanding of English words, this learning experience also enlarged their vocabulary, increased their interests in learning English, and enhanced their language senses. Other than those learning gains, most of participants found the collaborative learning arrangement of the activity improved their communication and cooperation skills. Friendship among peers was strengthened at the same time.

\subsection{Authentic Activity, Collaborative Design, and Using Cell Phones}

The distinguishing design features of this C-learning activity were the authentic activity, the collaborative learning approach, and using cell phone to facilitate English learning. These three features turned out to be students' favorite things in this activity as well. 
When asked to list three things that they liked the most in the activity, most students $(\mathrm{n}=51,69 \%)$ listed group collaboration and communication as one of their favorite parts of this learning activity. They believed that the collaborative learning approach increased their team spirit, exercised their ability of collaboration, encouraged them to share and learn from peers, and enhanced the friendship between group members. For example, one participant stated, "In this activity, I shared the learning process with my team members, and learned a lot from them" (Participant 68). Another participant said, "The interaction and communication between group members enhanced our understanding of each other, and cultivate the spirit of unity and cooperation" (Participant 4).

Many students $(\mathrm{n}=22,30 \%)$ found using cell phones for English learning interesting and convenient. To most of them, "It is [their] first experience using cell phones to learn English" (Participant 13). Participants commented that "the activity was interesting...[and] that cell phones can not only be used for having fun, but also for study" (Participant 30). Another participant said, "Using the communication tool, cell phones, to help English learning makes me feel that learning English is not confined to the classroom" (Participant 3).

Students ( $\mathrm{n}=33,45 \%)$ also enjoyed discovering English words used in daily life. Through searching English logos on the streets, they found learning English can occur anywhere any time, instead of being restricted to the classroom. They experienced real fun of learning English, "Learning English is no longer only for examination, but more relaxing" (Participant 13). As one participant stated, "English can be found in everyday life. [I] suddenly found English is on the side. It is a wonderful feeling. I like it" (Participant 21). Another student said, "This learning activity was close to daily life and was based on the environment we live in. We looked for English in our daily life, so I feel English is everywhere" (Participant 79).

Other students' favorite parts of this activity included sharing the final products with other students through presentations, finding different English writing styles, and the flexible design of this learning activity. Overall, students found that through this learning activity, they not only learned new English words $(\mathrm{n}=20$, $27 \%$ ), but also understood and memorized ( $\mathrm{n}=$ 20, 27\%) these English words better.

\subsection{Limitations}

Although this activity was generally welcomed by the students, it was not without limitations. Students' concerns of the activity were mainly about the limited time for collecting resources and presenting their final products, limited areas for locating English logos, limited quality of some cell phones, and collaboration issues such as role taking, free-riders, and group numbers. For example, some participants complained that "it was a waste of time to take a large amount of pictures" (Participants 9, 24, 85). For these concerns, students also provided suggestions accordingly. Students suggested moving the activity during breaks (e.g., winter break, summer break, national break) to extend the activity time. In terms of the limited areas with English signs and logos, students suggested extending the search area to include places out of the city. For example, they could take pictures of English street logos during their travels to other cities in breaks. Some students suggested including digital cameras and other digital devices as optional tools to solve the possible technical problems caused by cell phones.

The collaboration approach is mostly welcomed while always accompanied with some problems. Students suggested dividing roles for each group member and having flexible group sizes. In addition, a number of students also 
mentioned that they hoped that the instructor could be more involved in the activity such as providing suggestions and helping when they were developing PowerPoint presentations. Inspired by this activity, some students suggested including English words from movies, songs, and some brand names in future activities.

\section{Conclusion}

This study reported Chinese high school students' experiences of using a cell phone to complete an English learning activity. Specifically, this paper reported students' technological readiness for integrating cell phones into traditional English classes, students' perceived learning of the activity, and students' attitudes toward the learning activity. The design of the learning activity was based on Wang's (2010) combined task-based learning approach for EFL teaching, which emphasized task-based learning with authentic activity design, collaborative learning approach, and natural integration of cell phones. The appropriateness of this C-learning activity design was also explored by looking into students' feedback and comments. Findings of this study indicated that this C-learning activity design was appropriate for Chinese high school EFL teaching. The activity was welcomed by students. Students found C-learning interesting and effective for learning English. This study is an initial exploration of integrating C-learning into traditional EFL teaching. Further explorations on different activity designs and academic levels are expected to generalize the C-learning approach to a broader audience.

\section{References}

Ally, M. (2009). Mobile learning: Transforming the delivery of education and training. In M. Ally (Ed.). Athabasca, AB: Athabasca University Press.

Attewell, J. (2005). From research and devel- opment to mobile learning: Tools for education and training providers and their learners. Paper presented at the mLearn 2005, Cape Town, South Africa. http://www. mlearn.org.za/CD/papers/Attewell.pdf

Cavus, N., \& Ibrahim, D. (2008). A mobile tool for learning English words. Paper presented at the 5th International Conference on Electrical and Computer Systems (EECS' 08), Lefke, North Cyprus.

Cavus, N., \& Ibrahim, D. (2009). M-Learning: An experiment in using SMS to support learning new Egnlish languague words. British Journal of Educational Technology, 40(1), 78-91. doi: 10.1111/j.14678535.2007.00801.x

Creswell, J. W. (2005). Educational research: Planning, conducting, and evaluating quantitative and qualitative research (Vol. Pearson Education): Upper Saddle River, NJ.

Creswell, J. W., Clark, V. L. P., Gutmann, M. L., \& Hanson, W. E. (2003). Advanced mixed methods research designs. In A. Tashakkori \& C. Teddlie (Eds.), Handbook of mixed methods in social and behavioral research. Thousand Oaks, CA: Sage.

Cui, G., \& Wang, S. (2008). Adopting cell phones in EFL teaching and learning. Journal of Educational Technology Development and Exchange, 1(1), 69-80.

Gao, X. (2009). The "English corner" as an out-of-class learning activity. ELT Journal, 63(1), 60-67. doi: 10.1093/elt/ccn013

Griffith, S. (2008). Teaching English in Asia: Where and how to find ESL jobs. Retrieved from http:/www.transitionsabroad.com/ listings/work/esl/articles/workinasia.shtml

Kiernan, P. J., \& Aizawa, K. (2004). Cell phones in task based learning: Are cell phones useful language learning tools? ReCALL, 6(1), 71-84. doi: 10.1017/S0958344004000618

Leske, N. (2008). Chinese cellphone users tune into music. Retrieved from http://www.nytimes.com/2008/02/11/technology/11ihtcellphone.1.9924680.html?_r=1 
Librero, F., Ramos, A. J., Ranga, A. I., Trinona, J., \& Lambert, D. (2007). Uses of the cell phone for education in the Philippines and Mongolia. Distance Education, 28(2), 231244. doi: 10.1080/01587910701439266

Lucking, R. A., Christmann, E. P., \& Wighting, M. J. (2010). Cell phones for science. Science Scope, 33(5), 58-61.

McNicol, T. (2004). Language E-learning on the move. Retrieved from http://ojr.org/japan/wireless/1080854640.php

Oblinger, D. (2006). Simulations, games, and learning. Innovate, 2(4). Retrieved from http://www.educause.edu/ir/library/pdf/ ELI3004.pdf

Prensky, M. (2005). What can you learn from a cell phone? - Almost anything! Innovate: Journal of Online Education, 1(5), 8.

Pursell, D. P. (2009). Adapting to student learning styles: Engaging students with cell phone technology in organic chemistry instruction. Division of Chemical Education, 86(10), 1219-1222. doi: 10.1021/ ed086p1219

Roberson, J. H., \& Hagevik, R. A. (2008). Cell phones for education. Meridian Middle School Computer Technologies Journal, $11(2), 5$.

Saran, M., Seferoglu, G., \& Cagiltay, K. (2009). Mobile assisted language learning: English pronunciation at learners' fingertips. Eurasian Journal of Education Research, 34, 97-114.

Stead, G. (2005). Moving mobile into the mainstream. Paper presented at the mLearn 2005: 4th World Conference on mLearning, Cape Town, South Africa. http://www. mlearn.org.za/CD/papers/Stead.pdf

Taylor, R. P., \& Gitsaki, C. (2003). Teaching WELL in a computerless classroom. Computer Assisted Language Learning, 16(4), 275-294. doi: 10.1076/call.16.4.275.23412

Thornton, P., \& Houser, C. (2001). Learning on the move: Foreign language vocabulary via SMS. Paper presented at the ED-Media
2001 Norfolk, Virginia.

Twarog, L. I., \& Pereszlenyi-Printer, M. (1988). Telephone-assisted language study at Ohio state university: A report The Modern Language Journal, 72(4), 426-434.

Wang, F. (2010). Design Principles for cell phone learning in EFL. i-manager's Journal of Educational Technology, 7(2), 1-6.

Wang, F., \& Hannafin, M. J. (2005). Designbased research and technology-enhanced learning environments. Educational Technology Research and Development, 53(4), 5-23. doi: 10.1007/BF02504682

Wang, L. (2009). 2009 mobile phone sales in China reached 35.64 million total increase of $3.8 \%$ of chain. Retrieved from http://www.enet.com.cn/article/2009/0430/ A20090430466923.shtml

Wang, S., \& Higgins, M. (2006). Limitations of mobile phone learning. The JALT CALL Journal, 2(1), 3-14. doi: 10.1109/ WMTE.2005.43

Willis, J. (1996). A framework for task-based learning. London: Longman.

Yi, X. (2010). Phone against children can not be ignored: The amount of electromagnetic wave absorption over $60 \%$ of adults. Retrieved from http://www.zhichidai.com/ news/shehui/1054.html

\section{Contact the Authors}

Feihong Wang, Ph.D.

Virginia Polytechnic Institute and State University

Email: fwang06@vt.edu

Xin Chen, Ph.D.

Virginia Polytechnic Institute and State University

Email: chenxin@vt.edu

Weini Fang, Ph.D.

Xiamen Songbai Secondary School

Email:winnie1268@163.com 